\title{
MODERNISASI PENDIDIKAN ISLAM DAN PEMIKIRAN KEISLAMAN DI INDONESIA
}

\author{
Aziddin Harahap \\ Dosen Terap Sekolah Tinggi Ilmu Ekonomi Labuhan Batu, Indonesia
}

\begin{abstract}
Abstrak
Perkembangan pemikiran Islam sampai munculnya faham-faham keagamaan di dunia Muslim, senantiasa menarik untuk diamati. Sebab, dari perkembangan pemikiran itu dapat dilihat bagaimana corak pergerakan dan cara pandang keagamaan yang sangat memengaruhi kehidupan sosial, politik, dan budaya umat Islam. Pendidikan dan pemikiran keagamaan ikut membentuk sikap dalam berbuat dan bertindak. Masyarakat yang berafiliasi, berpendidikan dan berbudaya berupaya melakukan modernisasi kepada pemahaman baru yang lebih sesuai dengan kondisi sekarang (modern). Kebutuhan akan pemahaman baru muncul sebagai konsekwensi dari perkembangan peradaban. Kondisi pembaharuan diharapkan mampu menimbulkan kontak dengan hal-hal baru mulai dari budaya, bahasa, sikap, pemikiran, kebiasaan, perilaku, pendidikan, politik bahkan agama. Perilaku manusia identik dengan nuansa serta khasanah perkembangannya. Dalam hal ini khasanah yang dimaksud ada kalanya berimplikasi kepada Sikap pemahaman keagamaan.
\end{abstract}

Keyword : Modernisasi Pendidikan Islam, Pemikiran Keislaman

\section{Pendahuluan}

Perubahan pendidikan bersumber dari pemikiran-pemikiran tokoh pendidikan Islam, baik dari Nusantara hingga dunia Islam internasional, serta sikap politik dalam memberikan konfirmasi aktif demi kemajuan pendidikan. Konfirmasi terhadap dunia pendidikan merupakan kondisi riil yang dijalankan oleh masyarakat pendidikan dalam menjalankan aktivitas. Pendidikan pada intinya melibatkan manusia dalam menjalankan aktivitas keseharian dalam kemajuan dan pembaharuan. Banyak cara yang dilakukan manusia dalam hal menyikapi aktivitas, sehingga pembaruan dapat dimunculkan. Cara itu sendiri mampu mengarahkan pemikiran dan menformat sikap. Dalam hal ini manusia melibatkan agama sebagai kompas untuk mengarahkan jalan kerja aktivitas manusia di lembaga pendidikan. 
Manusia, pendidikan dan agama merupakan serangkaian komponen kehidupan mampu mewarnai khasanah pembaharuan yang dikenal dengan istilah modernisasi. Pada saat agama mempengaruhi kehidupan seseorang, di saat yang sama corak pemikiran keagamaan berimplikasi terhadap masyarakatnya. Pendidikan dan pemikiran keagamaan ikut membentuk sikap. Dalam hal ini melalui pendidikan berupaya melakukan modernisasi guna mengembrio pemikiran keagamaan yang diharapkan dapat direalisasikan terciptanya sikap politik ummat Islam. Realisasi dari sikap politik tersebut memunculkan modernisasi pendidikan Islam secara nasional ataupun internasional.

Mengingatkan proses modernisasi pendidikan hanya sebagai alat/instrumen untuk mensosialisasikan pemikiran-pemikiran modern. Pemikiran-pemikiran keagamaan seperti pemikiran Muhammad Abduh, Harun Nasution, juga gagasangagasan modernisasi Muhammadiyah dan lainnya. Dalam perkembangannya, pendidikan dan pemikiran keagamaan ikut membentuk sikap dan perilaku, hingga sikap dalam berbuat dan bertindak dapat terarah sebagaimana mestinya. Kebebasan berbuat dan bertindak diwarnai dengan tata cara dan arahan yang berlaku pada sekelompok manusia. Demikian halnya pada masyarakat yang berafiliasi, berpendidikan dan berbudaya berupaya melakukan modernisasi kepada pemahaman baru yang lebih sesuai dengan kondisi sekarang (modern). Kebutuhan akan pemahaman baru muncul sebagai konsekuensi dari perkembangan peradaban dunia pada umumnya dan peradaban Islam pada khususnya. ${ }^{1}$

\section{Pembahasan}

\section{A. Pemikiran keagamaan di Indonesia kontemporer: Radikalisme vs Liberalisme.}

\section{Pemikiran Keagamaan}

Perbedaan corak pemikiran dalam Islam adalah salah satu penyebab terpolarisasinya umat Islam ke dalam beberapa kelompok, antara lain berkenaan

\footnotetext{
${ }^{1}$ Hasan Asari, Modernisasi Islam Tokoh, Gagasan dan Gerakan Kajian tentang Perkembangan Moderen dalam Islam (Bandung: Cita Pustaka Media, 2007), h. 2.
} 
dengan corak pemikiran atau pemahaman dalam menghadapi masalah-masalah keagamaan. Bagi Muhammad Abduh misalnya, Islam adalah agama yang rasional, agama yang sejalan dengan akal, bahkan agama yang didasarkan atas akal. ${ }^{2}$ Pemikiran rasional baginya adalah jalan untuk memperoleh iman yang sejati. Penggunaan akal yang dominan dan anjurannya untuk langsung memahaminya dari al-Quran dan al-Sunnah, menjadikan ijtihad sebagai alat utama dalam menghadapi masalah-masalah keagamaan. Bentuk pemikiran yang kaku dalam melakukan penafsiran menempatkan agama di atas negara atau kekuasaan politik. Pemikiran ini merupakan pengaruh dari paham zuhud; di India oleh Akhmad Khan, di mana menganggap dunia tidak perlu (paham zuhud harus dinisbahkan), paham tawaqqal/menyerah diri dan paham fatalism/jabariah dipaksakan. Paham tawaqqal tidak sesuai dengan Islam. Akhirnya dikenal dengan paham qoda dan qodar oleh Muhammad Abduh, dunia menyatakan manusia melakukan pilihan. Pola pemikiran ini melahirkan ide modernisasi dari gemenshelf (primordial) kepada geselshelf (prestasi perjuangan). Dari pola yang sifat turun temurun yang digaungkan Ibnu Khaldun hingga sesuatu yang harus dikontrakkan

Paham dan pemikiran ini merembes di Nusantara. Pada masa awal Islam di kepulauan Nusantara, ummat Islam terpolarisasi menjadi dua kelompok, yaitu ummat Islam yang mengikuti aliran Syi'ah dan ummat Islam yang mengikuti aliran Ahl al-Sunnah ${ }^{3}$

Perjumpaan dua aliran tersebut ternyata menimbulkan persaingan dalam mempengaruhi pemimpin negara dan kalau mungkin merebut kekuasaan. Dalam catatan sejarah permusuhan pengikut aliran Syi'ah dan Ahl al-Sunnah dilatarbelakangi oleh politik kemudian berkembang ke ranah akidah, tarekat,

\footnotetext{
${ }^{2}$ Harun Nasution, Muhammad Abduh Dan Teologi Rasional Mu'tazilah (Jakarta: UI Press, 1987), h. 453.

${ }^{3}$ Mujamil Qomar, Fajar Baru Islam Indonesia (Bandung: Mizan, 2012), h. 37.
} 
filsafat dan tasawuf ${ }^{4}$ Karena itu pertentangan tersebut tampak kompleks sekali sehingga terus bermunculan dalam beberapa periode yang sulit didamaikan.

Dalam perkembangannya, ummat Islam Nusantara didominasi pengikut aliran Ahl al-Sunnah, baik yang Asy'ariyah maupun Maturidiyah, tetapi mayoritas pengikut Al-Asy'ari. Dalam praktik sehari-hari, sebenarnya ummat Islam Nusantara tidak murni mengikuti Al-Asy’ari sebagai representasi aliran Ahl alSunnah. Hal ini terjadi karena kurangnya pemahaman terhadap paham Ahl alSunnah; kurangnya kesadaran terhadap konsekwensi-konsekwensi dari pahampaham yang bermunculan

Pada dekade 1930-an gerakan Islam cenderung mengalami dinamika. Basis sosial Islam ketika itu nyaris terpolarisasi pada dua aliran trend, yaitu tradisionalis yang diwakili Nahdlatul Ulama (NU) dan aliran modernis yang diwakili Muhammadiyah $^{5}$

Hampir semua organisasi Islam mengklaim dirinya sebagai Ahl al-Sunnah, baik secara legal formal dinyatakan oleh institusinya, keputusannya maupun pengakuan tokohnya. Hal ini menunjukkan bahwa secara teologis, paham keagamaan mayoritas masyarakat muslim Indonesia adalah Ahl al-Sunnah. Tetapi mereka berbeda-beda dalam memaknai, menafsirkan dan menerjemahkan Ahl al-Sunnah itu dalam konteks aplikasi kehidupan keagamaan sehari-hari. Tidak jarang terjadi pertentangan di antara mereka dalam persoalan yang kecil-kecil furu'iyah akibat khilafiyah (perbedaan pandangan).

Pada 1970-an terdapat gelombang baru yang segaja diciptakan. Harun Nasution mengenalkan dan mempopulerkan gagasan teologi rasional ala Mu'tazilah di Indonesia ${ }^{6}$ Semangatnya mengenalkan teologi ini menyebabkan Harun Nasution sering disebut sebagai neo-Mu'tazilah. Pemikiran-pemikiran Mu'tazilah yang

\footnotetext{
${ }^{4}$ A.Hasjmy, Syiah dan Ahlussunnah: Saling Rebut Pengaruh dan Kekuasaan sejak Awal Sejarah Islam di Kepulauan Nusantara (Surabaya: Bina Ilmu, 1983), h. 46-50.

${ }^{5}$ Kuntowijoyo, Paradigma Islam: Intrepetasi untuk Aksi (Bandung: Mizan, 1991), h. 198.

${ }^{6}$ Fuad Jabali dan Jamhari (peny), IAIN dan Modernisasi Islam di Indonesia (Jakarta: Logos Wacana Ilmu, 2002), h. ix.
} 
disosialisasikan Nasution untuk membangkitkan semangat ummat Islam Indonesia dapat diterima oleh dosen maupun mahasiswa IAIN. Dosen-dosen yang berpengaruh, baik di UIN, IAIN, maupun STAIN di Indonesia ini, banyak sekali mendapatkan pengaruh dari pemikiran Mu’tazilah dari Nasution.

Seiring dengan arus modernisasi ummat Islam Indonesia mulai bergeser. Mereka mulai sedikit demi sedikit tetapi pasti berupaya untuk mengurangi fanatisme. Islam Indonesia adalah Islam inklusif dan nonsektarian, sehingga mereka responsif terhadap pemikiran dari luar. Islam bersifat inklusif yaitu suatu definisi yang dinamakan oleh penganut konsepsi tentang sistem sosial yang menekankan perlunya individu-individu dalam masyarakat dikontrol oleh kesetiaan menyeluruh kepada seperangkat sentral kepercayaan dan nilai ${ }^{7}$

Demikianlah paham keagamaan Islam Indonesia, dari paham tersebut ditarik garis lurus yaitu garis moderasi yang mampu menjembatani dua kubu pemahaman yang perlu ditelusuri untuk mengungkapkan Karakteristiknya.

Pengembangan pemikiran pendidikan Islam pada periode Indonesia merdeka (1945-sekarang). Wacana yang berkembang dengan proses terwujudnya integrasi pendidikan Islam ke dalam sistem pendidikan nasional menyoroti persoalan dalam pengembangan pemikiran pendidikan Islam Indonesia, a). Dikotomi ilmu pengetahuan. b). Kualitas pendidikan Islam.

Upaya membangun pendidikan Islam secara terpadu untuk mengembangkan manusia Indonesia seutuhnya. Dalam pemecahan masalah tersebut, seharusnya corak pemikiran pendidikan Islam yang lama seperti (a)Sintesa (penyempurnaan) dari berbagai sistem pendidikan yang pernah ada (b). Menumbangkan konsep dualisme antara ilmu agama dan ilmu umum. Sistem pendidikan yang sesuai dengan jiwa Islam. Menurut Karim, menyarankan bahwa tauhid sebagai landasan filosofis pendidikan Islam. ${ }^{8}$ Berikut pemaparan contoh pemikiran keagamaan yang

\footnotetext{
${ }^{7}$ Nurcholish Madjid, Islam Kemodernan dan Keindonesiaan (Bandung: Mizan,2013), h. 163.

${ }^{8}$ Karīm, Al-Fikr al-Islāmiy. Cet. II (Beirut: Dār al-Fikr, 1987, h.87.
} 
berlangsung dalam kajian sejarah pendidikan Islam Indonesia Corak pemikiran keagamaan yang berlangsung dalam kajian sejarah pendidikan Islam Indonesia.

\begin{tabular}{|c|c|c|c|}
\hline & Corak pemikiran keagamaan & & \\
\hline No & Corak Pemikiran Keagamaan lama & $\begin{array}{l}\text { Corak Pemikiran } \\
\text { Keagamaan Baru }\end{array}$ & $\begin{array}{l}\text { Pemikiran Keagamaan } \\
\text { Lama dan Baru }\end{array}$ \\
\hline 1 & $\begin{array}{ll}\text { a. } & \text { Ilmu yang sudah final : sintesa } \\
& \text { (penyempurnaan ) dari berbagai } \\
& \text { sistem pendidikan nyang } \\
& \text { pernah ada. } \\
\text { b. } & \text { Menumbangkan konsep } \\
& \text { dualisme antara ilmu agama dan } \\
& \text { ilmu umum }\end{array}$ & $\begin{array}{l}\text { Terbuka memahami al- } \\
\text { quran dan al-sunnah, } \\
\text { menjadikan ijtihad } \\
\text { sebagai alat utama } \\
\text { dalam } \\
\text { menghadapimasalah- } \\
\text { masalah agama }\end{array}$ & $\begin{array}{l}\text { Dikotomi ilmu } \\
\text { pengetahuan. Problem } \\
\text { tentang dikotomi antara } \\
\text { pendidikan agama dan } \\
\text { pendidikan umum }\end{array}$ \\
\hline 2 & $\begin{array}{l}\text { A Historis; isolatif tradisional ( corak } \\
\text { pendidikan pondok pesantren) dalam arti } \\
\text { tidak mau menerima apa saja yang } \\
\text { berbau kolonial (barat) }\end{array}$ & $\begin{array}{l}\text { antropo centri; lahir } \\
\text { organisasi -organisasi } \\
\text { dan di lanjutkan dengan } \\
\text { aktifitas-aktifitas } \\
\text { keagamaan yang } \\
\text { mengarah kepada } \\
\text { islamisasi budaya dan } \\
\text { politik secara massal. }\end{array}$ & $\begin{array}{ll}\text { a. } & \begin{array}{l}\text { Sintesis } \\
\text { (pertemuan }\end{array} \\
\text { corak lama dan } \\
\text { baru), yang } \\
\text { berwujud } \\
\text { madrasah }\end{array}$ \\
\hline 3 & Defensif & $\begin{array}{l}\text { Zuhud; sistem } \\
\text { pendidikan yang sesuai } \\
\text { dengan jiwa islam. } \\
\text { Pemahaman tawaqqal } \\
\text { tidak sesuai dengan } \\
\text { islam } \\
\end{array}$ & $\begin{array}{l}\text { Dari gemenshelf hingga } \\
\text { geselshelf primordial } \\
\text { dan prestasi }\end{array}$ \\
\hline 4 & Refetitif pola yang sifat turun temurun & $\begin{array}{l}\text { Qoda dan qodar; dunia } \\
\text { mengatakan manusia } \\
\text { melakukan pilihan- } \\
\text { pilihan }\end{array}$ & $\begin{array}{l}\text { Adanya penelitian } \\
\text { sehingga menemukan } \\
\text { teori-teori teknologi }\end{array}$ \\
\hline 5 & Social ecpection. Paham fatalistik & $\begin{array}{l}\text { Paham zuhud harus din } \\
\text { nisbahkan }\end{array}$ & $\begin{array}{l}\text { Negara wajib } \\
\text { memberikan jaminan. }\end{array}$ \\
\hline
\end{tabular}

\section{Menimbang Radikalisme dan Liberalisme}

Fenomena fundamentalisme dan radikalisme pesantren sesungguhnya sesuatu yang aneh, dan baru belakangan ini terjadi. Pesantren sebagai institusi keagamaan sebenarnya tidak didirikan untuk melahirkan radikalisme. Pesantren bertugas untuk mencetak kader-kader ulama yang berpengetahuan luas ${ }^{9}$ Karena itu,

${ }^{9}$ Marzuki Wahid, dkk (ed.).Pesantren Masa Depan, Bandung: Pustaka Hidayah. 1999. h.16 
pesantren mengajarkan semua hal yang ada di dalam agama; dari tauhid, syariat, hingga akhlak. Kesemuanya ini bertujuan agar selepas dari pesantren kelak, para santri dapat melakukan dakwah agama ke tengah-tengah masyarakat secara mumpuni.

Bahkan, karakter otentik pesantren dari zaman awal berdirinya pesantren sesungguhnya menampilkan wajahnya yang toleran dan damai. Di pelosok-pelosok pedesaan Jawa, Sumatera, dan Kalimantan, banyak ditemukan performance pesantren yang berhasil melakukan dialog dengan budaya masyarakat setempat. Pesantren-pesantren yang ada di Jawa, terutama yang bermazhab Syafi'i dan memiliki hubungan dekat dengan Nahdlatul Ulama (NU) menampilkan sikap akomodasi yang seimbang dengan budaya setempat. Sehingga pesantren mengalami pembauran dengan masyarakat secara baik. Keberhasilan pesantren seperti ini kemudian menjadi model keberagamaan yang toleran di kalangan umat Islam pada umumnya. Tak heran, jika karakter Islam di Indonesia seringkali dipersepsikan sebagai Muslim yang ramah dan damai. Karena itu, hampir tidak pernah terjadi proses radikalisasi di kalangan santri atas nama doktrin agama dalam bentuk aksi kekerasan.

Namun demikian, seiring dengan beragamnya corak pesantren di wilayah Nusantara; dari yang namanya pesantren Salaf/tradisonal; pesantren yang hanya mengajarkan ilmu-ilmu agama, khususnya Islam klasik, sampai kemudian dimarakkan dengan pesantren Khalaf/ modern, yang sudah mengajarkan mata pelajaran umum, wajah pesantren perlahan-lahan berubah. Pesantren tidak lagi menjadi agen perubahan sosial dengan kemampuanya beradaptasi dengan tradisi lokal, melainkan melakukan purifikasi yang luar biasa. Bahkan dalam beberapa kasus, pesantren justru memproduksi radikalisme secara doktrinal. Inilah yang kemudian ikut mempersubur gejala radikalisme di kalangan pesantren.

Di sinilah radikalisme pesantren harus dimaknai sebagai gugatan terhadap wajah pesantren pada umumnya yang telah mengajarkan agama tidak seperti yang diajarkan Rasulullah Saw. di masa-masa awal Islam. Gugatan demi gugatan dilakukan dengan melakukan purifikasi ajaran dan praktek keagamaan yang dianggap sinkretik secara besar-besaran. Dalam hal ini, mereka menginginkan agar 
semua pesantren tidak begitu saja menyesuaikan dengan tradisi lokal yang berbau bid'ah. Pada tahap selanjutnya, terjadilah radikalisme dalam wilayah doktrinal dan praktek keagamaannya.

Dalam konteks inilah, pesantren mesti melakukan introspeksi terhadap ajaran dasarnya agar tidak terlalu literal dan kaku dalam merespon perubahan zaman. Bukankah radikalisme pesantren justru menambah citra negatif masyarakat Muslim di tanah air? Dengan demikian, pesantren mesti dikembalikan ke dalam format awalnya sebagai pusat pendidikan agama yang mampu melakukan adaptasi dengan kebudayaan masyarakat setempat secara baik, tanpa harus saling menafikan. Dalam konteks selanjutnya, pesantren diharapkan dapat mencetak kader-kader muda beragama yang tidak bersikap apatis terhadap zaman, melainkan memunculkan optimisme terhadap masa depan kehidupan umat manusia yang mencerminkan toleransi dan perdamaian.

Sedangkan wacana liberalisme di kalangan pesantren memang terasa mengejutkan dan sering mengundang perdebatan. Apalagi, liberalisme jika dikaitkan dengan masalah agama, maka asumsi pertama yang muncul adalah menggugat kembali ide tersebut. Begitu pula ketika liberalisme dihubungkan dengan pesantren sebagai institusi sosial keagamaan, secara sadar akan melahirkan gugatan yang sama.

Gugatan yang berkaitan dengan wajah Islam yang dibawa pesantren ini muncul karena lembaga pendidikan tertua ini meniscayakan kepatuhan secara mutlak, kepasrahan, dan pengabdian, transendensi, dan pembatasan-pembatasan keilmuan yang diajarkan oleh kyai ${ }^{10}$ Sementara liberalisme terkait dengan filsafat dekonstruktif yang menisbikan kemutlakan, mendambakan kebebasan, dan anti transendensi ${ }^{11}$

mengungkapkan tentang beberapa karakteristik yang menandai lahirnya Islam liberal. Pertama, ingin melepaskan diri dari tradisi. Mereka datang dari

\footnotetext{
${ }^{10}$ Bruinessen, Martin Van. NU: Tradisi, Relasi-relasi Kuasa dan Pencarian Wacana Baru, Yogyakarta: LKIS 1994 h. 135.

${ }^{11}$ Binder, Leonard. Islamic Liberalism: A Critique of Development Ideologies. Oxford: Oxford University. 1988.h. 4-5
} 
tradisi, tetapi tradisi ini hanya dijadikan sebagai pijakan untuk melaksanakan tranformasi. Tradisi tidak diterima apa adanya atau ditentang mentah-mentah, melainkan diusung secara kreatif untuk melahirkan khazanah baru. Tradisi ini menyangkut tradisi keagamaan berikut tradisi keilmuan. Kedua, melepaskan beban sejarah umat Islam, dari sektarian-primordial menjadi pluralis universal. Tujuannya adalah mengkategorisasikan umat Islam sebagai bagian sejarah kemanusian universal yang berkeadilan dan demokratik yang tidak terbatas pada keinginan hegemonik politik dan menindas kelompok lain. Ketiga, menghindarkan diri dari pemaknaan harfiah teks-teks keagamaan yang dilakukan oleh para ulama pertengahan.

Pesantren di sini berfungsi sebagai entitas yang paling siap memanfaatkan tradisi sebagai bagian bangunan pembaruan khazanah kehidupan baru, tidak terkecuali seperti yang dilaksanakan oleh kelompok Islam liberal. Bahkan, KH Husein Muhammad menengarai akar-akar liberalisme sudah mulai tumbuh di lingkungan pesantren. Hanya saja, epistimologinya yang belum mereka kuasai. Pesantren mengajarkan pemikiran-pemikiran pluralistik, sehingga mereka cenderung menghargai keberagaman pemikiran, bersikap terbuka dan kritis. Hal ini dapat dilihat semakin intensifnya halaqah dan pelatihan di pesantren-pesantren mengenai tema-tema demokrasi, pluralisme, keadilan, kesetaraan gender, dan HAM. Tidak hanya itu, metodologi pemikiran yang dikatakan modern, seperti rasionalisme dan empirisme, juga telah menjadi kecenderungan baru para santri.

\section{B. Kaitan Perkembangan Pemikiran KeIslaman Dengan Modernisasi Pendidikan Islam.}

\section{Langkah-langkah Pembaharuan Pendidikan Harun Nasution}

Pembaharuan Islam dapat dipahami sebagai upaya dalam menyesuaikan pemahaman keagamaan Islam dengan perkembangan jaman terkini sebagai akibat dari kemajuan Ilmu Pengetahuan dan Teknologi (Iptek) modern ${ }^{12}$ Akan tetapi

\footnotetext{
${ }^{12}$ Hujar AH Sanaky, Paradigma Pendidikan Islam: Membangun Masyarakat Madani Indonesia (Yogyakarta: Safiria Insania Press, 2003), h. 9.
} 
pembaharuan Islam yang dimaksud ini bukan lantas merubah, mengurangai atau menambahkan teks dalam al-Quran dan al-Hadis, melainkan hanya merubah dan menyesuaikan paham atas keduanya sesuai dengan perkembangan baru yang ditimbulkan kemajuan Iptek tersebut. Hal ini dilakukan karena sebagus apapun paham-paham yang dihasilkan oleh para ulama atau pemikir terdahulu tetap ditemukan kekurangan dan selalu dipengaruhi oleh kecenderungan ilmu pengetahuan, situasi sosial, kebudayaan, dan lain sebagainya. Paham tersebut mungkin masih banyak yang relevan dan masih dapat digunakan, tetapi juga banyak yang sudah tidak sesuai lagi dengan kekinian

Selain itu, pembaharuan Islam dapat pula diartikan mengubah keadaan umat agar mengikuti ajaran yang terdapat di dalam Al-Quran dan Al-Hadis. Ini penting untuk dilakukan, karena telah ditemukan kesenjangan dalam kehidupan umat Muslim dari apa yang diisyratkan Al-Quran dan Al-Hadis, dengan kenyataan yang terjadi di masyarakat. Semisal, Al-Quran mendorong umat agar menguasai pengetahuan modern serta teknologi secara seimbang, hidup bersatu rukun dan damai, bersikap dinamis, kreatif, inovatif, demokratis, terbuka, menghargai orang lain, menghargai waktu, mencintai kebersihan dan lain-lain.

Namun pada kenyataannya, umat Islam menunjukkan keadaan yang berbeda. Sebagian besar umat Islam hanya menguasai pengetahuan agama sedangkan pengetahuan umum (modern) tidak dikuasainya, hidup dalam keadaan pertentangan dan peperangan, bersikap diktator, kurang menghargai waktu dan lain sebagainya. Keadaan yang demikian merupakan sikap dan pandangan hidup yang tidak sejalan dengan Al-Quran dan Al-Hadis. Sehingga perlu diperbaharui, dengan kembali kepada jalan yang diisyaratkan dua sumber ajaran Islam tersebut. Maka, pembaharuan Islam mengandung pema-haman mengembalikan sikap dan pandangan hidup umat Islam agar searah dan senafas dengan Al-Quran dan AlHadis $^{13}$

\footnotetext{
${ }^{13}$ Abuddin Nata, Metodologi Studi Islam, (Jakarta: Raja Grafindo Persada, 2014), h. 376.
} 
Namun, setelah itu Islam kembali menjadi objek dan tepuruk, di bawah dekte Barat, khususnya dalam perkembangan Iptek. Harun Nasution menyimpulkan, setelah Islam terpuruk, menjadi kehilangan gairah dan semangatnya untuk bangkit kembali. Bukan semangat kejayaan Islam yang berkembang setelah itu, bahkan hingga sekarang, namun semangat menerima apapun yang terjadi karena dipercaya itulah ketentuan Allah Swt yang harus diterima. Semangat tradisional bukan semangat modern yang selalu mengawal kemajuan dan perkembangan zaman. Maka, semangat itulah yang perlu diperbaharui oleh Islam, menghilangan pemahaman tradisional dirubah menjadi pemahaman baru dan modern untuk kembali merebut kejayaan Islam. Dengan paradigma demikian, harapan untuk melepaskan umat Islam dari suasana kemunduran saat ini dan selanjutnya umat Islam hijrah (beranjak) kepada kemajuan akan nyata ${ }^{14}$

Setelah kembali ke Indonesia dan menjadi intelektual muslim, Harun getol mewacanakan pembaharuan Islam. Dalam bukunya Pembaharuan Dalam Islam; Sejarah Pemikiran dan Gerakan, muncul ide-ide pembaharuan dengan maksud mengembalikan sikap dan pandangan hidup umat Islam agar sesuai dengan AlQuran dan Al-Hadis. Ia mencontohkan seperti apa yang dilakukan Muhammad Abduh, yang mengemukakan ide-ide pambaharunya antara lain dengan cara menghilangkan bid'ah yang terdapat dalam ajaran Islam, kembali kepada ajaran Islam yang sebenarnya, dibukanya kembali pintu ijtihad, menghargai pendapat akal dan menghilangkan sikap dualisme dalam bidang pendidikan ${ }^{15}$ Harun juga mencontohkan salah seorang tokoh pembaharu Islam di India, Sayyid Ahmad Khan, dimana teori Ahmad Khan mengatakan untuk mencapai kemajuan perlu meninggalkan paham teologi Jabariah (fatalism) diganti dengan paham Teologi Qadariah (free will dan free act), perlu percaya bahwa hukum alam dengan wahyu yang ada dalam Al-Quran tidak bertentangan, karena kedua-duanya berasal dari Tuhan dan perlu dihilangkan paham taklid diganti dengan paham ijtihad.

\footnotetext{
${ }^{14}$ Harun Nasution, Pembaharuan Dalam Islam; Sejarah Pemikiran dan Gerakan, (Jakarta: Bulan Bintang, 1992), Cet. IX. 13. h. 11.

${ }^{15}$ Ibid., 62-67.
} 
Perkembangan perubahan yang terjadi di Timur Tengah telah memunculkan tradisi baru di al-Azhar, inilah yang menjadi salah satu rujukan utama pendirian IAIN. Di antara fakultas di IAIN, tiga diantaranya sama dengan fakultas di al-Azhar sejak 1930-an: Fakultas Ushuluddin, Syari`ah dan Adab. Sistem ujian tahunan juga diambil dari al-Azhar. Salah satu faktor yang mendukung pengaruh model al-Azhar adalah banyaknya lulusan al-Azhar yang memegang kedudukan penting di Departemen Agama dan merancang pendirian IAIN. Namun, belakangan terjadi perubahan dan pembaruan lebih mendasar menyangkut isi program studi dan metode pengajaran. Pembaruan ini dilakukan ketika Harun Nasution menjabat rektor IAIN Syarif Hidayatullah (1973-1984) dan kemudian diterapkan berangsurangsur pada IAIN-IAIN lain.

Perubahan tersebut diilhami baik oleh kebijakan pembangunan nasional yang mensyaratkan dimensi kehidupan keagamaan yang rasional dan dinamis, maupun oleh tradisi akademis Barat. Tidak dapat diragukan bahwa pengalaman Harun Nasution yang pernah belajar di al-Azhar dan meraih gelar doktor di Institute of Islamic Studies, Universitas McGill, Kanada, merupakan salah satu faktor yang mendorong pembaruan IAIN. Saat yang sama, perubahan itu menekankan bahwa IAIN harus menjadi lembaga pengembangan ilmu pengetahuan agama, bukan pusat doktrin Islam seperti pada periode sebelumnya.

Lantas bagaimana penerapannya dalam pendidikan Islam. Harun dengan gamblang mengutarakan untuk merobah pola pendidikan Islam tradisional ke arah yang pendidikan Islam yang modern. Dengan memasukkan mata pelajaran tentang ilmu-ilmu pengetahuan modern ke dalam kurikulum sekolah Islam atau madrasahmadrasah. Harun juga meminta kepada para pemangku kebijakan dan pemikir Islam, untuk mendirikan sekolah-sekolah Islam atau madrasah modern di samping madrasah-madrasah yang telah ada, sebagai madrasah percontohan. Dengan ini diharapkan, muncul-muncul ahli-ahli Islam dalam bidang Iptek. Mereka inilah yang akan membawa umat kepada kemajuan dalam kehidupan duniawi. ${ }^{16}$

\footnotetext{
${ }^{16}$ Harun Nasution, Pembaharuan Dalam Islam; Sejarah Pemikiran dan Gerakan.(Jakarta: Bulan Bintang, 1992). Cet. IX. h. 208.
} 
Salah satu indikator tentang orientasi IAIN adalah kerjasama internasional. Sebelumnya, hubungan luar negeri Indonesia dalam bidang kajian Islam lebih berorientasi ke Timur Tengah. Akan tetapi belakangan semakin banyak tenaga pengajar dan/atau lulusan IAIN yang melanjutkan studi di dunia Barat. Gejala itu sudah ada sejak 1960-an, tapi semakin kuat sejak akhir 1980-an. Kebanyakan mahasiswa dan peneliti ini dikirim ke Universitas McGill dan Leiden, sedangkan jumlah lebih kecil dikirim ke berbagai universitas di Amerika Serikat, Australia, dan negara Barat lain ${ }^{17}$

\section{Langkah-langkah Pembaharuan Pendidikan Munawir Sjadzali}

Selama menjabat Menteri agama, tidak sedikit kebijakan yang telah diambil Munawir Sjadjali. Setidaknya ada tiga agenda yang paling menonjol. Pertama, menuntaskan Pancasila sebagai asas organisasi sosial-kemasyarakatan. Kedua, pembenahan lembaga-lembaga pendidikan Islam. Ketiga, penguatan keberadaan Pengadilan Agama dan Kompilasi Hukum Islam ${ }^{18}$ Munawir sangat getol melakukan pembenahan di bidang pendidikan, khususnya pendidikan di wilayah Departemen Agama. Hal ini karena, menurutnya, pendidikan merupakan media yang paling tepat untuk menyiapkan calon pemimpin bangsa yang tangguh ${ }^{19}$ Oleh karena itu, ada tiga agenda besar yang menjadi pikiran Munawir yang harus segera dituntaskan.

Pertama, terkait dengan masalah IAIN. Meskipun telah berdiri puluhan tahun, sebagai lembaga pendidikan tinggi agama negeri, pada saat itu, IAIN belum memiliki dasar hukum yang kuat. Juga anggaran belanjanya jauh di bawah perguruan tinggi umum negeri yang dikelola oleh Departemen Pendidikan dan Kebudayaan. Untuk menuntaskan penataan IAIN ini menurutnya sangat rumit. Namun dengan usaha kerasnya melobi dua departemen (Departemen Pendidikan

\footnotetext{
${ }^{17}$ Kamaruzzaman Bustamam-Ahmad, Melacak Akar Sosial-Politik Intelektual Islam Indonesia: Sebuah Survey Bibliografis, https://kyotoreview.org/issue-8-9/melacak-akar-sosialpolitik-intelektual-islam-indonesia-sebuah-survey-bibliografis/. 10 April 2018.

${ }^{18}$ Azyumardi Azra (Ed.), Menteri-menteri Agama RI; Biografi Sosial-Politik (Jakarta: Kerjasama INIS, PPIM, dan Badan Litbang Agama Departemen Agama RI, 1998), hlm. 394.

${ }^{19}$ Abdurrahman Kisdi, Munawir Sjadzali dan Internasional Studies; Menembus Kebekuan Pendidikan Islam, Makalah, 2008. Sumber: http://www.ditpertais.net/jurnal/vol62003lo.asp.
} 
dan Kebudayaan yang pada waktu itu dijabat oleh Dr. Nugroho Notosusanto dan Menteri Pendayagunaan Aparatur Negara yang dijabat oleh Prof. Dr. Saleh Afif) masalah pembenahan IAIN ini dapat terselesaikan dengan diterbitkannya Peraturan Pemerintah Nomor 33 tahun 1985 yang memberikan status, perlakuan, dan fasilitas kepada 14 IAIN di seluruh Indonesia sama dengan perguruan tinggi umum negeri yang dikelola oleh Departemen Pendidikan dan Kebudayaan. PP itu dijabarkan dengan keputusan Presiden Nomor 9 tahun 1987, dan kemudian merupakan bagian dari Undang-undang Nomor 2 tahun 1989 tentang Sistem Pendidikan Nasional.

Kedua, terkait dengan penataan jenjang pendidikan di bawah IAIN yaitu Madrasah Ibtidaiyah, Tsanawiyah, Aliyah dan Pesantren. Dalam rangka penetapan tersebut, satu rintisan Pak Mukti Ali melalui SKB Menteri 1975 yang bertujuan mengangkat kondisi madrasah sejajar dengan kondisi sekolah-sekolah umum, perlu adanya penyempurnaan atau koreksi, yang dalam istilahnya Abdullah Sukarta terpaksa Munawir sempurnakan ${ }^{20}$ Ketiga, Menghidupkan kembali tradisi pengiriman dosen IAIN untuk studi ke negara-negara Barat khususnya ke Universitas McGill, (Montreal, Kanada) dan Universitas Leiden (Belanda)- yang dulu pernah dirintis Mukti Ali. Menurutnya, ilmuwan Muslim Indonesia yang mampu berkomunikasi dengan dunia modern adalah mereka yang di samping mendapat pendidikan S1 di Timur, juga mengenyam pendidikan S2 dan S3 di Barat. Munawir menunjuk nama-nama seperti Prof. Dr. HM. Rasjidi, Prof. Dr. Mukti Ali, dan Prof. Dr. Harun Nasution sebagai prototype ilmuwan Muslim Indonesia.

Pada periode 1988-1991, program pengiriman dosen ini mengalami sukses besar. Menurut catatan Munawir, selama ia menjadi Menteri Agama, Departemen Agama telah mengirim sebanyak 225 mahasiswa ke Barat. Mereka diterima untuk program S2 dan S3 di universitas-universitas Barat, seperti McGill di Kanada; UCLA di Columbia, Chicago, dan Harvard di USA; London, Leiden, dan Hamburg di Eropa Barat; serta ANU, Monash, dan Flinders di Australia. Sampai awal tahun 1993, dari mereka itu telah kembali ke Indonesia sebanyak 12 orang dengan menyandang gelar Ph.D dan sebanyak 67 orang dengan gelar MA. Dan sekitar 200-

\footnotetext{
${ }^{20}$ Abdullah Sukarta, Dari Thamrin Hingga Ke Banteng Kilas Balik Bersama Pak Munawir, dalam Kontekstualisasi Ajaran Islam (Jakarta: Paramadina, 1995), h. 153.
} 
an orang tamatan Madrasah Aliyah dikirim ke Kairo untuk melanjutkan studi di Universitas al-Azhar. ${ }^{21}$ Terhadap pengiriman dosen ke Barat, Munawir memberikan alasan (1) agar para lulusan IAIN dapat lebih memperluas cakrawala ilmiah mereka dan belajar untuk berpikir kritis terhadap ilmu pengetahuan termasuk ilmu keagamaan, (2) agar tidak terjadi kesenjangan dan demi terjadinya komunikasi yang lancar dan serasi dengan mitra-mitra perjuangan mereka yang berpendidikan Barat.

\section{Kesimpulan}

Perkembangan pemikiran Islam sampai munculnya faham-faham keagamaan di dunia Muslim, senantiasa menarik untuk diamati. Sebab, dari perkembangan pemikiran itu dapat dilihat bagaimana corak pergerakan dan cara pandang keagamaan yang sangat memengaruhi kehidupan sosial, politik, dan budaya umat Islam. Pendidikan dan pemikiran keagamaan ikut membentuk sikap dalam berbuat dan bertindak. Masyarakat yang berafiliasi, berpendidikan dan berbudaya berupaya melakukan modernisasi kepada pemahaman baru yang lebih sesuai dengan kondisi sekarang (modern). Kebutuhan akan pemahaman baru muncul sebagai konsekwensi dari perkembangan peradaban. Kondisi pembaharuan diharapkan mampu menimbulkan kontak dengan hal-hal baru mulai dari budaya, bahasa, sikap, pemikiran, kebiasaan, perilaku, pendidikan, politik bahkan agama. Perilaku manusia identik dengan nuansa serta khasanah perkembangannya. Dalam hal ini khasanah yang dimaksud ada kalanya berimplikasi kepada Sikap pemahaman keagamaan.

Pemahaman keagamaan ummat Islam di Indonesia berkembang di mana didominasi oleh Mazhab Syafi'i. Dalam bermazhab umumnya ummat Islam Indonesia masih bermazhab secara tekstual atau mengikuti ungkapan-ungkapan mujtahid (bermazhab secara qauli), belum bermazhab secara metodologis (bermazhab secara manhaji), yaitu dengan cara mengikuti pola berfikir mujtahid

${ }^{21}$ Ibid., 154. 
dalam mengistimbath hukum atau mengikuti jalan pikiran dan kaidah penetapan hukum yang telah disusun oleh imam mazhab.

\section{DAFTAR PUSTAKA}

Asari, Hasan. Modernisasi Islam Tokoh, Gagasan dan Gerakan Kajian Tentang Perkembangan Modern dalam Islam, Bandung: Cita Pustaka Media, 2007.

Bruinessen, Martin Van. 1994. NU: Tradisi, Relasi-relasi Kuasa dan Pencarian Wacana Baru, Yogyakarta: LKIS.

Binder, Leonard. 1988. Islamic Liberalism: A Critique of Development Ideologies. Oxford: Oxford University.

Hasjmy, A. Syiah dan Ahlussunnah: Saling Rebut Pengaruh dan Kekuasaan sejak Awal Sejarah Islam di Kepulauan Nusantara, Surabaya: Bina Ilmu, 1983.

Jabali, Fuad. dan Jamhari (peny), IAIN dan Modernisasi Islam di Indonesia, Jakarta: Logos Wacana Ilmu, 2002.

Kuntowijoyo, Paradigma Islam: Intrepetasi untuk Aksi, Bandung: Mizan, 1991.

Karīm, Al-Fikr al-Islāmiy. Cet. II (Beirut: Dār al-Fikr, 1987,

Madjid, Nurcholish. Islam Kemodernan dan Keindonesiaan, Bandung: Mizan, 2013.

Muin, Abd. 2007. Pendidikan Pesantren dan Potensi Radikalisme, Jakarta: Prasasti.

Nasution, Harun. Muhammad Abduh Dan Teologi Rasional Mu'tazilah, Jakarta: UI Press, 1987.

Qomar, Mujamil. Fajar Baru Islam Indonesia, Bandung: Mizan, 2012.

Wahid, Marzuki. dkk (ed.). 1999. Pesantren Masa Depan, Bandung: Pustaka Hidayah.

Zaqzuq, Mahmud Hamdi. 2004. Reposisi Islam di Era Globalisasi, Yogyakarta: LkiS. 